POLITICS AND INTERNATIONAL RELATIONS

\title{
The Policy-Making Capacity of Foreign Ministries in Presidential Regimes: A Study of Argentina, Brazil, and Mexico, 1946-2015
}

\author{
Octavio Amorim Neto ${ }^{1}$ and Andrés Malamud ${ }^{2}$ \\ 1 Getulio Vargas Foundation, BR \\ 2 Institute of Social Sciences, University of Lisbon, PT \\ Corresponding author: Andrés Malamud (amalamud@ics.ulisboa.pt)
}

\begin{abstract}
This article investigates the sources of foreign ministries' policy-making capacity in presidential regimes. Using the concept of family resemblance, we argue that professionalization of the diplomatic corps is a necessary condition, whereas the institutional attributions of the ministry and the degree of presidential delegation are relevant but substitutable elements. The higher the scores on either of the latter dimensions, the stronger is the capacity of the foreign ministry to influence the chief executive and to contest other players' policy preferences. To empirically validate our concept, we measure the three dimensions in Argentina, Brazil, and Mexico between 1946 and 2015 using data on diplomats' recruitment and career paths, influence of diplomatic schools and doctrines, appointment patterns of foreign ministers, and relevance of presidential diplomacy, with an emphasis on travels abroad. Our analysis indicates that Argentina, Brazil, and Mexico enjoy a high level of professionalization of their diplomatic corps; however, differences - both across countries and over time-remain regarding institutional attributions and presidential delegation.
\end{abstract}

Este artículo investiga las fuentes de la capacidad de formulación de políticas en los ministerios de relaciones exteriores de regímenes presidenciales. Utilizando el concepto de "parecido de familia", sostenemos que la profesionalización del cuerpo diplomático es una condición necesaria, mientras que las atribuciones institucionales del ministerio y el grado de delegación presidencial son elementos relevantes pero intercambiables. Cuanto más alto sea el puntaje en cualquiera de las dos últimas dimensiones, mayor será la capacidad del ministerio para influenciar al presidente y doblegar las preferencias de otros actores. Para validar empíricamente el concepto, medimos sus tres dimensiones en Argentina, Brasil y México entre 1946 y 2015 utilizando datos sobre reclutamiento y carrera diplomática, influencia académica y doctrinas diplomáticas, patrones de nombramiento de ministros y relevancia de la diplomacia presidencial con énfasis en viajes internacionales. Nuestro análisis indica que Argentina, Brasil y México hoy disfrutan de un alto nivel de profesionalización de su cuerpo diplomático. Sin embargo, persisten grandes diferencias - entre países y en el tiempo- en lo que hace a las atribuciones institucionales y el grado de delegación presidencial.

\section{Introduction}

Itamaraty, as Brazil's foreign ministry is known, is often acclaimed as one of the world's strongest. In contrast, Mexican diplomats and scholars routinely complain that their country's foreign ministry is understaffed and underresourced (Figueroa and Schiavon 2014). Yet Brazil's foreign prestige seems diminished and Itamaraty's diplomatic grip eroded (Malamud 2017). The third traditional Latin American power, Argentina, has recently gone the opposite way, from diplomatic pariah to international praise, despite chronic political instability and the politicization of key diplomatic posts (Roblas 2011). This reversal of fortune is puzzling. Is the stabilizing presence of a powerful foreign ministry increasingly 
irrelevant in current times? We cannot know: the literature lacks an instrument for measuring the policymaking capacity of the office-there is not even consensus on the concept's definition. Filling this lacuna is a prior step to any further research.

The goal of this article is to conceptualize the policy-making capacity of foreign ministries and to operationalize the concept. Although foreign ministries have been losing their grip on foreign policy over decades and all over the world (Hocking 1999b), their policy-making capacity varies widely, and we need to better understand the conditions underlying such variation. Only afterward will it be possible to assess causal claims regarding foreign policy outcomes.

Our theoretical focus is on presidential regimes because almost two-thirds of the world's democratic countries have an elected chief of state (Samuels and Shugart 2010,6) to whom foreign ministers are not peers but subordinates. Presidential systems, either pure or semipresidential, are the dominant executive type among democracies, but the literature on foreign ministries covers mostly European and Commonwealth parliamentary polities (Hocking 1999a; Hocking and Spence 2003; Steiner 1982). The comparative study of foreign ministries in presidential systems is long overdue.

Our empirical focus is on Argentina, Brazil, and Mexico between 1946 and 2015. Our case selection is based on three facts. First, Latin America features the world's strongest presidentialist tradition. Second, our cases are the largest powers in the region, which confers greater impact to their foreign policy-making process. Third, our cases exhibit wide variation in all dimensions underlying the policy-making capacity of foreign ministries.

\section{The Concept of Foreign Ministries' Policy-Making Capacity}

On the basis of the Latin American and US experience, we distill the concept of a foreign ministry with high policy-making capacity into its component parts. Following the tenets of concept formation (Goertz 2006), we combine elements of the necessity-and-sufficiency structure together with an additive or family resemblance approach.

Governmental capacities can be divided in three categories: steering (provision of direction), maintenance (provision of stability), and political (provision of legitimacy). The institutional infrastructure and personal skills required for enhancing each capacity vary widely and are often in tension with one another. Concentration of power, for instance, tends "to perform better at the steering tasks of government than those that diffuse power" (Weaver and Rockman 1993, 454). Correspondingly, diffusion of power is more closely related to maintenance (stick to commitments) and political (wide representation and social peace) capacities (Rockman 1997). In the case of a state agency, policy-making capacity depends on the degree to which the agency can perform the three tasks with the least intromission from other agencies.

At the primary or theoretical level of the concept, we define the policy-making capacity of a foreign ministry as the capacity to insulate itself from the steering will of other government authorities, therefore being able to advance its own preferences on other state bureaucracies and to implement such preferences while retaining internal and external legitimacy. Its opposite pole is a foreign ministry with low policymaking capacity, and a gray area lies in between.

At the secondary level of conceptualization, a foreign ministry with high policy-making capacity is constituted by three features: the professionalization of the diplomatic corps, ample institutional attributions, and extensive presidential delegation of diplomatic affairs to the foreign ministry. The first feature is a necessary condition. The second and third features are substitutable: a foreign ministry can have its policy-making capacity heightened either by institutional attributions or by extensive presidential delegation.

At the third or indicator level of the concept, there are two necessary elements that signal the professionalization of the diplomatic corps: competitive recruitment to the diplomatic career and promotion based on formal studies and merit.

In contrast, there are two substitutable indicators of the institutional attributions of foreign ministries: either they have legal jurisdiction over key policy areas and offices, or they are subject to low policy competition from other state bureaucracies or both. Increased professionalization in other sectors of government (e.g., agriculture, finance), as well as the rise of intragovernmental networks derived from new information and communication technologies, explains the growing competition arising from other ministries and the concomitant weakening of foreign ministries across the board.

Likewise, there are three substitutable indicators of presidential delegation. Presidents delegate to the foreign ministry either by displaying a relatively low diplomatic activism or by maintaining a relatively stable ambassadorial elite composed mostly of career diplomats or by appointing foreign ministers with a 
relatively autonomous power basis. Note that nothing prevents these features from being cumulative. That is, the more a president delegates, the greater the policy-making capacity of a foreign ministry. Figure $\mathbf{1}$ illustrates our conceptual structure.

\section{The Professionalization of the Diplomatic Corps}

The first constitutive feature of a foreign ministry with high policy-making capacity is the professionalization of the diplomatic corps. As with any necessary condition, its absence has a stronger effect than its presence (Mahoney, Kimball, and Koivu 2009). Think of a modern foreign ministry whose officials are nonprofessional political appointees. This will be a heavily politicized diplomatic corps whose competence may always be questionable. This also means that these diplomats are unlikely to have a strong esprit de corps, a key factor in the institutionalization of any bureaucracy. In the classic definition by Huntington (1968, 12): "Institutionalization is the process by which organizations and procedures acquire value and stability. The level of institutionalization of any political system can be defined by the adaptability, complexity, autonomy, and coherence of its organizations and procedures." In a foreign ministry, these features are decisively affected by the degree of professionalization of the diplomatic corps.

As regards complexity, a nonprofessional diplomatic corps will be a much simpler organization because it is the expertise of professional bureaucrats that leads to "both multiplication of organizational subunits, hierarchically and functionally, and differentiation of separate types of organizational subunits" (Huntington 1968, 18).

Autonomy means that an organization is not penetrated by, or easily made an instrument of, outside groups and actors. The professionalization of the diplomatic corps, by creating high barriers to such groups and actors, is the decisive step to a foreign ministry's achieving autonomy. The indicators of professionalization are competitive recruitment and promotion based on merit. We consider both to be necessary elements because competitive recruitment without promotions based on merit leads to the destruction of the human capital generated by the former. Promotions based on merit but without previous competitive recruitment are baseless, as the starting point may be too low for the value of merit to set root.

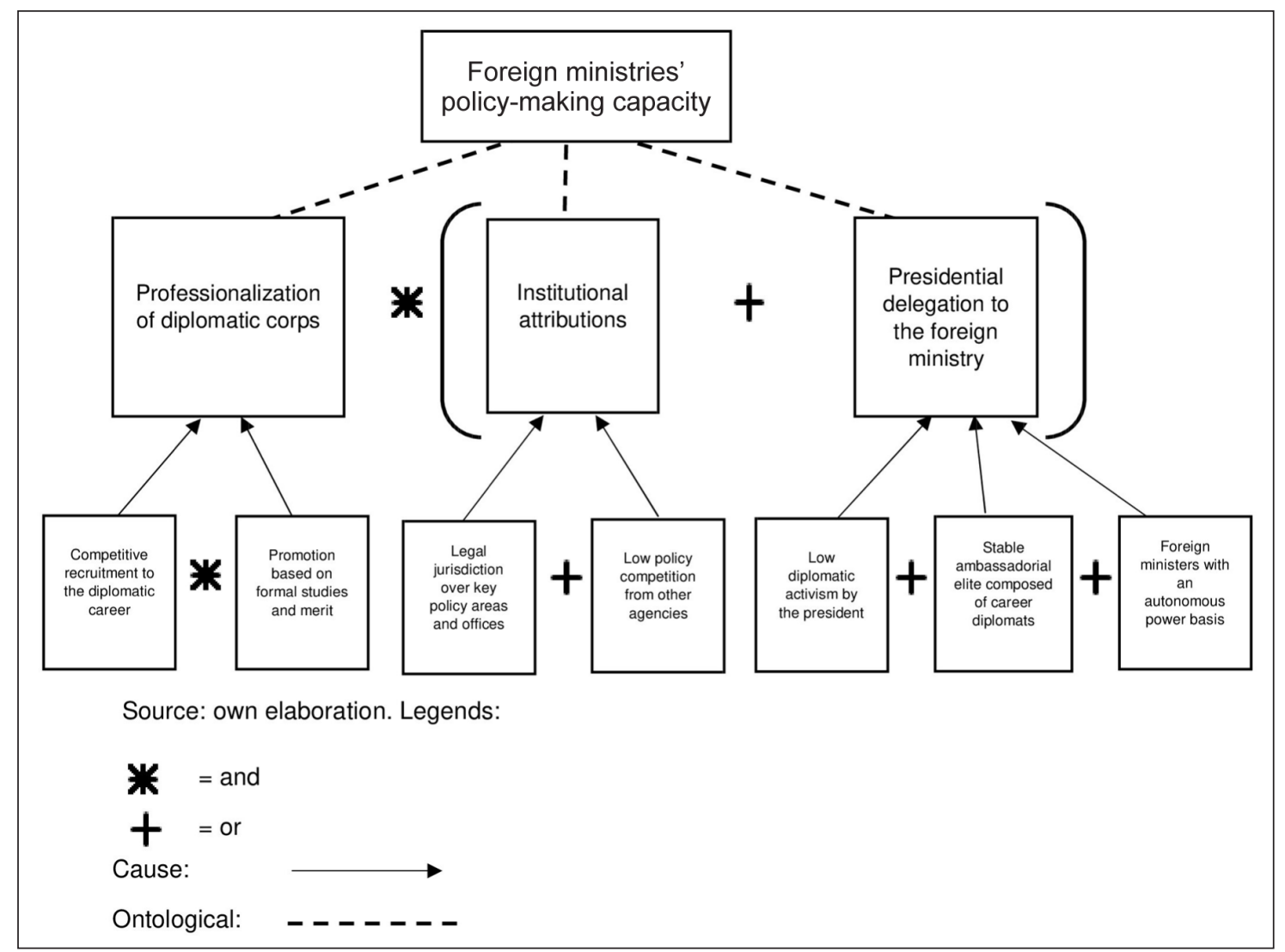

Figure 1: The structure of the concept of foreign ministry policy-making capacity in presidential regimes. (An asterisk indicates and; a plus sign indicates or. A solid line indicates cause; a dashed line indicates ontological). 
As for coherence, in a nonprofessionalized foreign ministry, characterized by the prevalence of political appointees, the diplomatic corps is unlikely to have a doctrine with a lasting effect in shaping and homogenizing the worldview, preferences, and behavior of its servants.

\section{The Institutional Attributions of Foreign Ministries}

In addition to the professionalization of the diplomatic corps, a foreign ministry can have its policy-making capacity heightened by institutional attributions over policies and offices. In the old days of diplomacy, foreign ministries used to enjoy a quasi monopoly over international affairs. With states' growing functions, the proliferation of their attendant bureaucracies, the complexification of international relations, and never-ending revolutions in transportation and communications technologies, foreign ministries began to suffer competition on their own turf from other ministries and state agencies. Nowadays, they might have to compete with nongovernmental organizations and subnational governments for influence over foreign policy making (Hocking 1999b). Hence, two substitutable indicators of institutional attributions signal high policy-making capacity: either the ministries have legal jurisdiction over key policy areas and offices or they are subject to low policy competition from other state bureaucracies. For example, if a foreign ministry has a monopoly over trade policy, this will maximize its political power within government and society. The foreign ministry is further empowered if diplomats are legally entitled to monopolize the holding of key offices.

Another pathway through which foreign ministries see their policy-making capacity heightened is weak peer competition. Take the counterexample of the US Department of State. The State Department is often seen as a relatively weak agency because, in spite of its able bureaucracy, it faces a tough policy competition from the Pentagon, the Office of the US Trade Representative, the National Security Council, and the Central Intelligence Agency (East and Dillery 1999). Conversely, if a foreign ministry were to compete for access to the president's ear with a recently established and poorly institutionalized Ministry of Defense then it is likely to see its policy-making capacity maximized.

\section{Presidential Delegation to the Foreign Ministry}

Even if a foreign ministry does not enjoy extensive attributions, it can be empowered by presidential delegation. This is a highly political and therefore easily revocable constitutive element of policy-making capacity, much more so than professionalization and institutional attributions. After all, presidents come in many forms. Some have no interest in, or familiarity with, foreign policy. Such presidents are more willing to delegate to the professionals in the foreign ministry, thus heightening its policy-making capacity. Other presidents are keen on international affairs or are forced to handle foreign policy crises. These presidents are likely to exert tighter control over the conduct of diplomatic business. Chief executives with these concerns are likely to put their cronies in key diplomatic posts, thus diminishing the foreign ministry's policy-making capacity.

We posit that there are three substitutable indicators of presidential delegation of foreign policy authority to foreign ministries. First, presidents delegate when they are not active on foreign policy. This delegation may be more or less implicit. Purposely or not, diplomatically inactive presidents are more likely to empower the foreign ministry than active ones.

The second substitutable indicator of presidential delegation is the maintenance of a relatively stable ambassadorial elite composed mostly of career diplomats. Given that the appointment of ambassadors is always a presidential attribution, the decision to fill a country's key diplomatic posts with professional diplomats is a sign of presidential delegation that heightens the foreign ministry policy-making capacity. Now take again the counterexample provided by the United States: although Washington has a professional diplomatic corps, most American ambassadors are presidential cronies or campaign donors (Arias and Smith 2018). This diminishes the policy-making capacity of the State Department.

Finally, the third substitutable indicator of presidential delegation is the appointment of foreign ministers with an autonomous political basis. Let us recall that ordinary bills of law are a less necessary tool for foreign policy than for other policy areas. In diplomacy, major changes can be effected through speeches delivered by a chief executive or decisions made by her or him unilaterally. It also means that the translation of the preferences of presidents into foreign policy will depend more on the control the chief of government has over the bureaucratic apparatus than on legislative majorities. No wonder US presidents spend a good deal of their time, especially during presidential transitions, trying to find the right people for diplomatic and national security posts.

When it comes to appointing foreign ministers, presidents for whom foreign policy is a salient issue will prefer the selection of experts or bureaucratic operators who know the ins and outs of the diplomatic 
apparatus, able to provide technical expertise and familiarity with personnel, routines, and standard operating procedures (Allison and Zelikow 1999, 143-196). The more a president wants to control foreign policy, the less that president will be willing to delegate authority to the diplomatic corps. Hence, the chief executive will be less inclined to appoint a foreign minister with an autonomous political basis, such as, for example, a powerful party leader or legislator. This kind of president is even likely to appoint a diplomat to head the foreign ministry. Diplomats offer the president the double benefit of being politically weak, therefore controllable, and knowing the inner workings of the bureaucracy. Paradoxically, the appointment of diplomats to head the foreign ministry diminishes its policy-making capacity, whereas the appointment of a political heavyweight signals that the president is willing to delegate authority.

If low presidential activism or a professional criterion of ambassadorial appointments or a partisan selection of foreign ministers becomes a pattern, then presidential delegation is routinized as a sort of informal institution, further heightening the policy-making capacity of the foreign ministry. ${ }^{1}$

\section{Measures}

The challenge, then, is to develop measures of our seven indicators that can be applied to our three casesand beyond, to any presidential polity.

Some of the indicators are easy to operationalize. For example, regarding competitive recruitment and merit-based promotion, we simply provide information on when each of the three countries began to recruit diplomats through competitive calls, when they established a diplomatic school, and when formal studies began to affect career promotions.

Likewise, with respect to legal jurisdiction over key policy areas and offices and policy competition from other state bureaucracies, we first ask whether and when trade policy fell under the jurisdiction of the foreign ministry. We also ask whether and when there was a top position within the ministry (e.g., deputy foreign minister) reserved for diplomats. Then, is there a ministry of defense? If each branch of the armed forces has its own ministry, life is easier for the foreign ministry because the soldiers, diplomats' most traditional competitors, are divided. Is there a national security council? Since when? Is there a powerful foreign affairs adviser at the presidential palace who is not a member of the diplomatic corps? In addition, for each country we ask whether a ministry other than defense has emerged to compete with the foreign ministry. We did not compare foreign ministries' budgets because a cursory search confirmed that their size is systematically small and shows little variation over time.

We use simple statistics for the three indicators of presidential delegation: diplomatic activism by presidents, the stability and professional makeup of the ambassadorial elite, and the recruitment criteria for foreign ministers. For diplomatic activism, we adopt the measure proposed by Cason and Power (2009): the percentage of each president's term consumed with international travels. For the stability and makeup of the ambassadorial elite, our first step was to evaluate the frequency at which presidents change the chiefs of the top-ten embassies, on the assumption that the less a president changes the key diplomatic legations, the more authority she or he delegates. Although a president could leave untouched the leadership of all the embassies and even so relegate the foreign ministry to a secondary role, this is unlikely: from the president's point of view, it would be a waste of patronage opportunities. Moreover, keeping the key ambassadors appointed by previous administrations could jeopardize the president's foreign policy. As the translation of the president's preferences into actual policies depends more on the control over the diplomatic apparatus than on legislative majorities, the most effective ways for a president to gain it is the appointment of trustworthy people to key positions. As for the professional makeup of the ambassadorial elite, we look at the proportion of the heads of top-ten embassies that are professional diplomats. The higher the proportion, the more the president delegates to the foreign ministry.

Concerning the appointment criteria of foreign ministers, we present data on the frequency at which such ministers were affiliated with parties, held legislative office, were career diplomats, and were foreign policy experts. We aggregate data on foreign ministers per regime because, as mentioned previously, if the selection criteria of foreign ministers result in a discernible pattern across presidential terms, then it is easier to observe the degree of entrenchment of presidential delegation of policy authority to the foreign ministry.

\footnotetext{
Rodman makes it clear how presidential delegation has been key to the policy-making capacity of the US Department of State: "One of the ... lessons of recent history is that strong secretaries of state who enjoy the confidence of the president have managed to restore the department to a position of leadership in the government" $(2010,286)$.
} 


\section{Argentina's Foreign Ministry: From High Reputation to High Instability}

Adopted in 1853, the Argentine constitution established five ministries, one of which was Foreign Affairs. In 1898, a constitutional amendment increased the number of ministries to eight but left them unnamed. In 1994, another amendment eliminated any numerical restrictions, yet Foreign Affairs remained among the most traditional ministries-which is not tantamount to powerful. Given Argentina's turbulent financial history, the minister of the economy rose gradually to be the strongest cabinet member.

Until the advent of Peronism in 1946, the prestige carried by the foreign ministry manifested in the stature of the men who held the office. Future presidents, literary figures, jurists, and even a Nobel Prize awardee served as Argentine foreign ministers. Even between 1916 and 1930, when the popularly based Unión Cívica Radical came to power, both radical presidents Hipólito Yrigoyen and Marcelo T. de Alvear appointed renowned party figures to the post.

The main benchmarks in the history of the ministry are the attribution of religious affairs to its competencies in 1898, the moving of its headquarters to Palacio San Martín in 1936, the creation of the National Foreign Service Institute (Instituto del Servicio Exterior de la Nación, or ISEN) in 1963, the attribution of foreign trade to its competencies in 1992 (together with the transference to the diplomatic corps of related civil servants), and the reallocation of this competence back to the economy ministry in 2011.

ISEN was founded under the initiative of foreign minister Carlos Muñiz during the interim presidency of José María Guido, which suggests that there was neither long-term planning not democratic or technocratic legitimacy behind it. Yet not only did ISEN survive; it also turned into the exclusive mechanism of selection for the foreign service. Since its foundation, it has recruited annual cohorts without discontinuity.

What was the foreign ministry like before its professionalization? Until the 1943 military coup that gave birth to Peronism, Argentine diplomacy was characterized by aristocratic recruitment and institutional porousness: the upper classes that ran the government also ran the ministry. Increasing professionalization contributed to the isolation of foreign policy making from social struggles, but democratic instability kept it hostage to political infighting. At least until the Falklands/Malvinas War, in 1982, networks of civilians and military officers routinely disputed the ear of the president and the conduct of foreign affairs (Bosoer 2005).

\section{The International Travels of the President}

Between 1955 and 1983, Argentine presidents were short-lived and their administrations consumed by domestic problems. Indeed, the first president to finish a constitutional term after 1952 was Carlos Menem, in 1995. International trips accurately reflect this situation: before 1989, only President Arturo Frondizi (1958-1962) spent abroad more than 4 percent of his term (Figure 2). Héctor Cámpora's exception is because he did not reach two months in office.

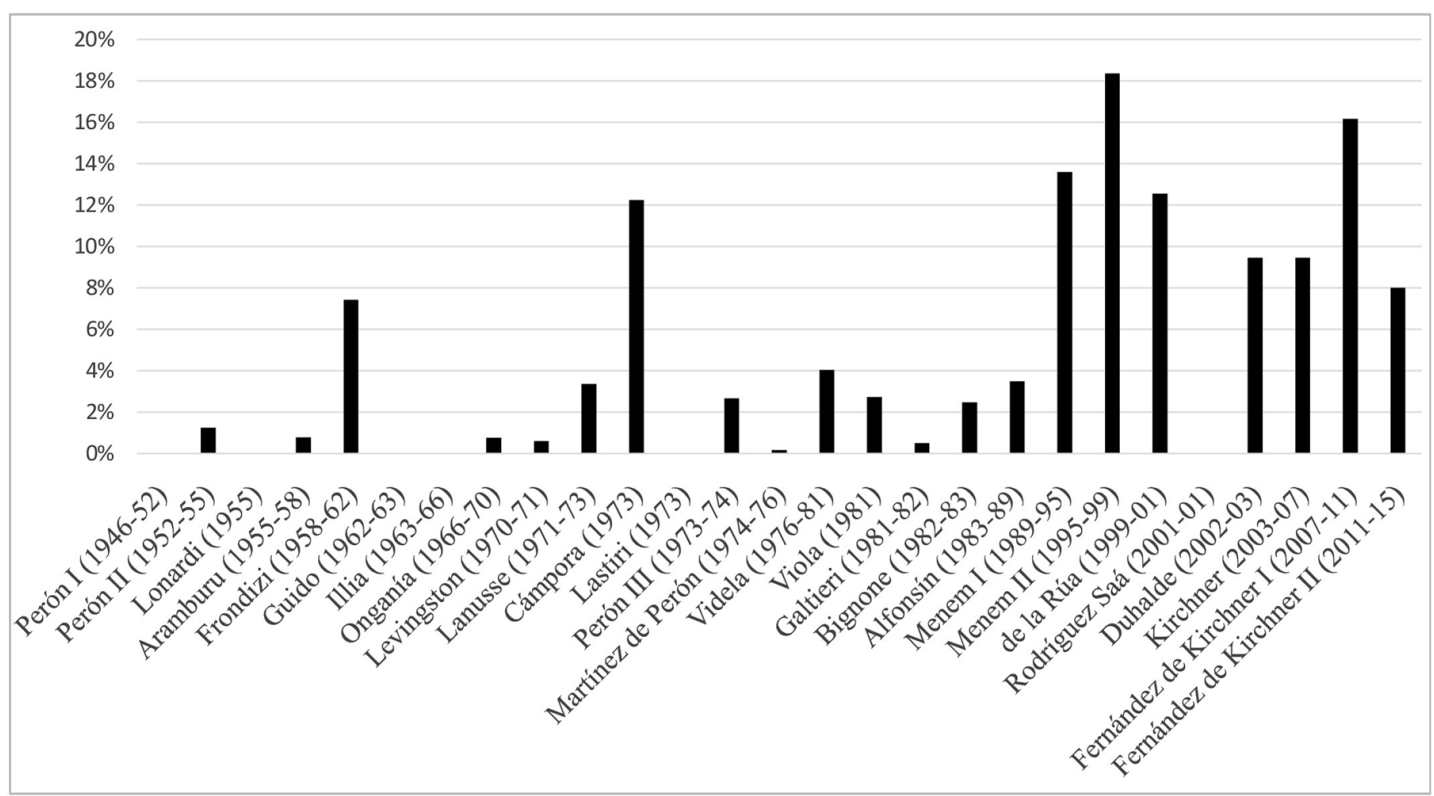

Figure 2: Percentage of term spent abroad by Argentine presidents, 1946-2015 (Cisneros and Escudé 2000; Boletín Oficial de la República Argentina, https://www.boletinoficial.gob.ar). 
Although Raúl Alfonsín (1983-1989) earned international renown, he delegated most traveling to his foreign minister Dante Caputo. Yet the personal relationship that Alfonsín built with Brazil's José Sarney (Mallea, Spektor, and Wheeler 2015) set the stage for what would become the region's diplomatic cornerstone for years to come: interpresidential diplomacy.

Presidential diplomacy is an increasingly frequent complement to professional diplomacy. When presidents are active on foreign affairs, they have constitutional and political means to prevail over foreign ministers, diplomats, and Congress. Malamud (2005) showed how President Menem was able to circumvent Guido Di Tella, the longest-serving foreign minister in Argentine history, and how even politically weakened president Fernando de la Rúa (1999-2001) managed to circumvent an unreceptive Congress. Under Cristina Kirchner (2007-2015), so-called parallel embassies-that is, presidential envoys that lacked formal appointmentmanaged foreign relations with strategic partners like Iran and Venezuela, fully bypassing formal diplomatic channels.

\section{The Ambassadorial Elite}

We analyzed the stability of the chiefs of missions in Argentina's top-ten embassies between 1946 and 2015. Selection was based on political or commercial salience over all or a significant part of the period. Our assumption is that the less a president changes the leadership of the key diplomatic legations, the more authority she or he delegates to the diplomatic corps. Table 1 shows the frequency of changes between 1946 and 2015. The embassies under scrutiny are neighboring powers Brazil and Chile; great European powers France, Germany, Italy, Soviet Union/Russia, Spain and United Kingdom; the UN mission; and the United States.

The three presidents who effected more changes in their first year in office were constitutional chiefs of state, radical Illia (1963-1966), Peronist Menem (1989-1995) and radical De la Rúa. This suggests that the degree of stability of the ambassadorial elite was independent from the political party. Thus, a pattern of instability and uncertainty emerges; surprisingly enough, this pattern has been more accentuated after democratic turnover than after democratic breakdown.

Article 5 of the foreign service legislation allows the executive to exceptionally appoint ambassadors who do not belong to the diplomatic career-up to a limit of twenty-five since 1995. Our data indicate that two embassies (France and Italy) have had nonprofessional ambassadors for more than two-thirds of that period, four (Brazil, Chile, Spain, and United States) did alike for between one-third and two-thirds of the period, and the remaining four embassies (Germany, Russia, United Nations, and United Kingdom) were led by noncareer diplomats for less than one-third of the period. According to confidential sources, the only distinguishable pattern is that Paris and Rome were considered too appealing to be given to anyone other than personal friends or political allies. We also detected three temporal patterns: in 1946-1973, most of the top ambassadors were not career diplomats; in 1973-2003, there was a trend toward appointing a majority of career diplomats, thus empowering the foreign ministry; under the Kirchners (2003-2015) the trend reverted toward politicization.

\section{Foreign Ministers}

We identified forty-eight ministers during the period under review. While some stayed a long time in office, others did not complete a month. We discarded the interim appointees and ended up with a universe of thirty-nine ministers. The first is Perón's Juan Atilio Bramuglia, and the last is Fernández's Héctor Timerman.

There have been three kinds of ministers: political henchmen who were entirely subordinated to democratically elected presidents (especially under Peronist administrations); experts whose reputation allowed them a certain margin of maneuver, if always under the aegis of the president (General Roberto Viola's Oscar Camilión, Alfonsín's Dante Caputo, and Néstor Kirchner's Jorge Taiana are cases in point); and civilians who served under military rule and were appointed to soften the edges of the regime but lacked leeway to maneuver. There was also a small number of military officers who held the post during military administrations: three out of five did so during the 1976-1983 dictatorship, as Table 2 shows. The presence of a foreign policy adviser has been uncommon.

Whenever the competences of the foreign minister have been challenged, the rival has been the minister of economy (under unconstitutional regimes, the military would address their concerns directly to the president). In disputes between ministries, the economy minister would customarily carry the day. The autonomy of the foreign minister has varied not according to linear but rather to cyclical and irregular paths.

In short, in the early 1960s Argentina's foreign ministry began to fill the necessary condition for high policy-making capacity, but its scores on measures of the additive elements do not indicate further 
Table 1: Changes promoted by Argentine presidents in top ten embassies, 1946-2015.

\begin{tabular}{|c|c|c|c|c|}
\hline President & $\begin{array}{c}\text { Ambassadors } \\
(n)^{\mathrm{a}, \mathrm{b}}\end{array}$ & $\begin{array}{c}\text { Changes } \\
\text { made in first } \\
\text { yearc }^{c}\end{array}$ & $\begin{array}{c}\text { Ambassadors } \\
\text { designated } \\
(n)^{\mathrm{d}}\end{array}$ & $\begin{array}{c}\text { Career } \\
\text { diplomats } \\
\text { appointed }\end{array}$ \\
\hline Perón I (1946-1952) & 24 & 6 & 17 & $12 \%$ \\
\hline Perón II (1952-1955) & 15 & 4 & 9 & $11 \%$ \\
\hline Lonardi (1955) & 13 & 4 & 4 & $0 \%$ \\
\hline Aramburu (1955-1958) & 14 & 2 & 6 & $17 \%$ \\
\hline Frondizi (1958-1962) & 20 & 5 & 12 & $17 \%$ \\
\hline Guido (1962-1963) & 13 & 4 & 4 & $0 \%$ \\
\hline Illia (1963-1966) & 21 & 7 & 12 & $0 \%$ \\
\hline Onganía (1966-1970) & 16 & 4 & 6 & $33 \%$ \\
\hline Levingston (1970-1971) & 10 & 3 & 3 & $33 \%$ \\
\hline Lanusse (1971-1973) & 12 & 1 & 3 & $0 \%$ \\
\hline Cámpora (1973) & 8 & 1 & 1 & $0 \%$ \\
\hline Lastiri (1973) & 7 & 0 & 0 & - \\
\hline Perón III (1973-1974) & 10 & 4 & 4 & $50 \%$ \\
\hline Martínez de Perón (1974-1976) & 13 & 2 & 3 & $67 \%$ \\
\hline Videla (1976-1981) & 20 & 5 & 12 & $50 \%$ \\
\hline Viola (1981) & 15 & 6 & 6 & $17 \%$ \\
\hline Galtieri (1981-1982) & 10 & 2 & 2 & $50 \%$ \\
\hline Bignone (1982-1983) & 12 & 4 & 4 & $75 \%$ \\
\hline Alfonsín (1983-1989) & 19 & 6 & 11 & $82 \%$ \\
\hline Menem I (1989-1995) & 28 & 7 & 24 & $54 \%$ \\
\hline Menem II (1995-1999) & 20 & 1 & 10 & $50 \%$ \\
\hline De la Rúa (1999-2001) & 14 & 10 & 10 & $80 \%$ \\
\hline Rodríguez Saá (2001) & 9 & 0 & 0 & - \\
\hline Duhalde (2002-2003) & 14 & 4 & 4 & $0 \%$ \\
\hline Kirchner (2003-2007) & 14 & 5 & 8 & $25 \%$ \\
\hline Fernández de Kirchner I (2007-2011) & 17 & 4 & 10 & $40 \%$ \\
\hline Fernández de Kirchner II (2011-2015) & 14 & 3 & 5 & $20 \%$ \\
\hline
\end{tabular}

Sources: Historical Archive of the Ministerio de Relaciones Exteriores y Culto; List of Foreign Ministers of Argentina, by Project Gutenberg (n.d).

${ }^{a}$ We did not have access to all ambassadorial appointments. The table includes the available data.

${ }^{\mathrm{b}}$ Total number of ambassadors who served in top ten embassies, for each presidential term.

${ }^{\mathrm{C}}$ Number of ambassadors changed in the first year of presidency in top ten embassies.

${ }^{\mathrm{d}}$ Total of ambassadors appointed by a president for these embassies, in each presidential term.

e Percentage of career diplomats appointed over the total of "ambassadors designated $(n)$ " in top ten embassies.

empowerment on a stable basis. Under the current democratic regime (1983 to present), the main source of policy-making capacity has been the sporadic appointment of foreign ministers-whether party politicians or public intellectuals-with a relatively autonomous political basis.

\section{Brazil: The Rise and Fall of Itamaraty}

In the 1930s a consensus was reached among Brazilian political elites on the need for a professional diplomatic career (Cheibub 1985). In 1945 a law requiring competitive examinations for entry into the diplomatic service was promulgated, and a diplomatic school, Instituto Rio Branco, was founded. Since then, those beginning a career are required to study for two years at this school. As of 1945, promotions 


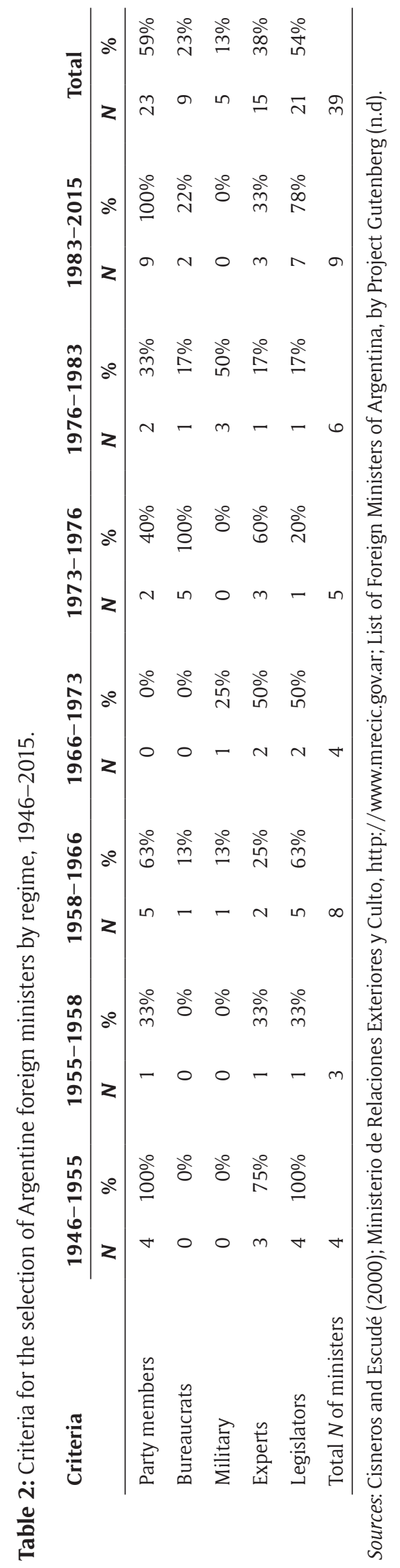


began to be affected by performance evaluations and academic degrees, particularly after the reforms enacted in 1961 (Castro and Castro 2009, 1:449-503). It is no wonder, then, that Brazil is seen today as having one of the world's most professionalized diplomatic corps.

What was Itamaraty like before its professionalization? Despite the prestige the charismatic Baron of Rio Branco, foreign minister from 1902 to 1912, had bestowed on the ministry, his recruitment policy was consistent with the country's patrimonial and oligarchic practices. Besides, his centralizing decision-making style weakened the foreign ministry's organizational structure (Cheibub 1985, 120-123). Only in the early 1930s did this weakening begin to be reverted.

As for institutional attributions, since 1946 all deputy foreign ministers have been career diplomats, but this post was legally monopolized only in 2010. We see in this formal or informal control over the country's second most relevant diplomatic office an evidence of institutional autonomy.

As regards trade policy, control has varied. In the 1940s and 1950s the foreign ministry was the paramount player. However, the Ministry for Trade and Industry, created in 1960, assumed important attributions. In 1999 this office was renamed to Ministry of Development, Industry, and Foreign Trade, and saw its influence enhanced. Since the early 2000s, the Ministry of Agriculture began to demand a greater voice. Although Itamaraty still negotiates trade agreements and promotes trade abroad, it has lost hold over trade policy, especially after the creation of the Câmara de Comércio Exterior (CAMEX, or Foreign Trade Chamber) under the Fernando H. Cardoso administration (an interministerial agency dealing with foreign trade). Itamaraty recovered certain de facto degree of control under Lula (Coelho 2014), but it suffers peer competition from the Ministry of Development, Industry, and Foreign Trade as well as the Ministry of Agriculture. Three periods are visible as concerns Itamaraty's relations with trade policy: 1946-1960, almost complete control; 1961-1998, ample control; and 1999-2015, contested and declining control.

With regard to competition from defense-related agencies, note first that in 1946-1998, the army, navy and air force had each a ministry. The armed forces were very influential in Brazil's first democratic experience in 1946-1964 (Stepan 1988). Then, during the 1964-1985 military regime, they became hegemonic. In the outset of the new democratic regime initiated in 1985, they retained considerable attributions and autonomy, with each branch entitled to a cabinet minister plus the president's military chief of staff and the head of the Joint General Staff, both offices with cabinet rank (Stepan 1988). However, with the limitation of many attributions and the creation of a Ministry of Defense in 1999, the domestic power of the military waned until Michel Temer took the presidential office in May 2016.

During the military regime, Brazil had a National Security Council (Conselho de Segurança Nacional, or CSN) with considerable influence over foreign and defense policy. By a 1969 decree, CSN became the "highest level organ to directly advise the President of the Republic on the formulation and implementation of national security policy" (CSN 1969, article 40). However, throughout the 1980s CSN saw its functions increasingly reduced. Since 1988 Brazil has a National Defense Council, but the council holds no influence over defense or foreign policy, and it rarely holds meetings.

Brazil's Ministry of Defense (MoD) was always led by a civilian between 1999 and 2015, which contributed to curtailing the political sway of the armed forces. Moreover, it became increasingly influential over Brazil's grand strategy since the publication of the National Defense Strategy in 2008, which was complemented in 2012 by the country's first white book on national defense. In 2010, a bill was passed that strengthened the role of the defense minister in the conduct of defense policy and created the position of joint chief of staff of the armed forces.

There are five periods in terms of competition between Itamaraty and defense-related agencies. The first is the 1946-1964 democratic regime: while the armed forces were divided into three ministries, they monopolized defense policy and held extensive political influence. The second period is the military regime, during which the armed forces monopolized political power and national security policy but were willing to delegate a good deal of foreign policy authority to Itamaraty. The third, 1985-1989, is a transition period. The fourth period is 1990-1998, during which the sharp fall in the armed forces' political power played into the hands of Itamaraty. The last period begins with the creation in 1999 of the civilian-led MoD, whose growing influence over grand strategy has meant a stronger peer competitor for Itamaraty.

Finally, from January 2003 to May 2016 there existed the office of special adviser to the presidency for international affairs, which was held by a leader of the Workers' Party, Marco Aurélio Garcia. He was influential in the making and implementation of foreign policy toward Latin America (Pinheiro and Milani 2012). Therefore, in 2003-2015 Itamaraty faced an additional source of competition for access to the president's ear. 
Summing up, although from 1946 to 1989 Brazil's foreign ministry faced tough competition from the armed forces, the military regime did not interfere much with Itamaraty's internal business because of a mixture of reciprocity (as a consequence of diplomats' acquiescence to the authoritarian order) and contempt (because diplomats were seen as playing old-style, lace-cuffed diplomacy) (Miyamoto and Gonçalves 1993). Between 1985 and 1999 the foreign ministry was in the ascendant. However, in the twenty-first century, Itamaraty has been facing growing competition from the MoD; the Ministry of Development, Industry, and Foreign Trade; the Ministry of Agriculture; and last but not least, the special adviser to the presidency. The key policy attribution that the foreign ministry still enjoys is its monopoly over posts within the ministry, particularly the office of deputy foreign minister and the heads of almost every embassy.

\section{The International Travels of the President}

Brazil's diplomacy has been increasingly presidentialized (Amorim Neto 2011; Cason and Power 2009; Danese 1999; Malamud 2005), having reached its peak during the Lula administration. Cason and Power's $(2009,123)$ data show that Cardoso and Lula were the chief executives who presidentialized the conduct of foreign policy the most through international travels.

Figure 3 indicates that from Ernesto Geisel (1974-1979) on, the frequency of international travels by presidents goes up. Before, only João Goulart (1961-1964) had stood out. The period between 1946 and 1973 was characterized by low presidential activism as compared to 1974-2015. Presidential diplomacy peaked under Cardoso and Lula and then started a downward trend.

\section{The Ambassadorial Elite}

Table 3 shows the frequency of changes of Brazil's top-ten ambassadors between 1946 and 2015 per presidency. The embassies considered are United States, Argentina, Portugal, Spain, Germany, France, Italy, United Kingdom, United Nations, and the World Trade Organization's General Agreement on Tariffs and Trade (GATT-WTO). All have existed since the 1940s.

The main trend is that the frequency of changes is highest under the current democratic regime. All else constant, the first year is the most important because it is when the president is forming her government and setting the policy agenda. The 1946-1964 regime and the military regime are relatively similar with regard to the changes observed in the first years. In addition, the first government of each regime always effects more changes. The first year of both Cardoso and Lula are those scoring the most changes. This is strong evidence that they had a keen concern with the control of the ambassadorial elite.

The frequency of career diplomats leading the country's top embassies has been growing over the three successive regimes: 71.0 percent for 1946-1964, 83.6 percent for 1964-1985, and 86.7 percent

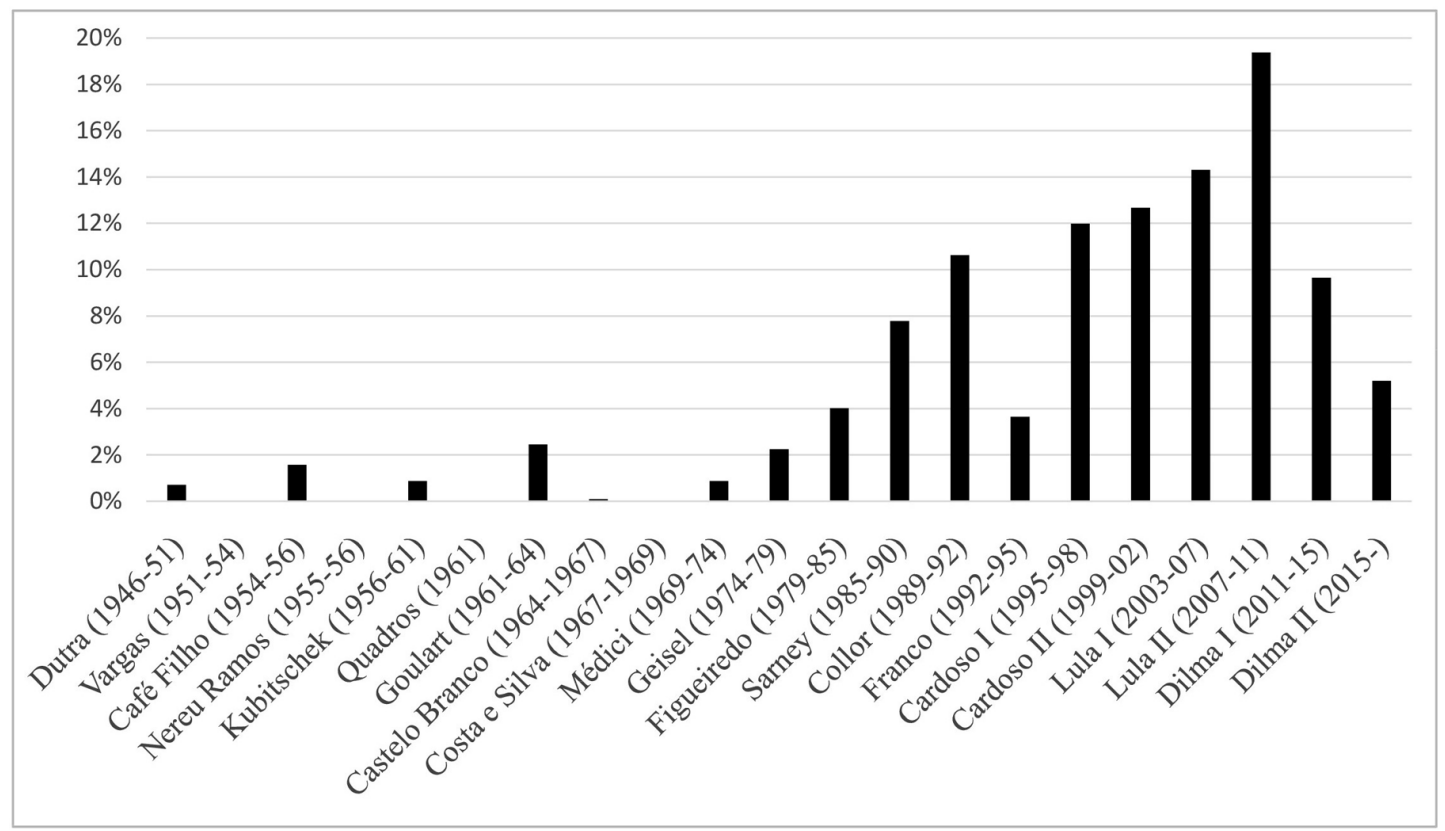

Figure 3: Percentage of term spent abroad by Brazilian presidents, 1946-2015 (Garcia 2005; Brazil: Ministério das Relações Exteriores, http://www.itamaraty.gov.br). 
Table 3: Changes promoted by Brazilian presidents in top ten embassies, 1946-2015.

\begin{tabular}{lrrrr} 
President & $\begin{array}{c}\text { Ambassadors } \\
(\boldsymbol{n})^{\mathbf{a}}\end{array}$ & $\begin{array}{c}\text { Changes } \\
\text { made in }^{\text {first year }}{ }^{\mathbf{b}}\end{array}$ & $\begin{array}{c}\text { Ambassadors } \\
\text { designated }^{(\boldsymbol{n})^{\mathbf{c}}}\end{array}$ & $\begin{array}{c}\text { Career } \\
\text { diplomats }_{\text {appointed }^{\mathbf{d}}}\end{array}$ \\
\hline Dutra (1946-1951) & 18 & 2 & 12 & $83 \%$ \\
Vargas (1951-1954) & 18 & 2 & 10 & $60 \%$ \\
Café Filho (1954-1955) & 13 & 3 & 4 & $100 \%$ \\
Ramos (1955-1956) & 9 & 0 & 0 & 0 \\
Kubitschek (1956-1961) & 20 & 5 & 12 & $58 \%$ \\
Quadros (1961) & 8 & 1 & 1 & $100 \%$ \\
Goulart (1961-1964) & 15 & 3 & 8 & $88 \%$ \\
Castelo Branco (1964-1967) & 19 & 6 & 12 & $83 \%$ \\
Costa e Silva (1967-1969) & 18 & 3 & 9 & $78 \%$ \\
Médici (1969-1974) & 17 & 4 & 8 & $75 \%$ \\
Geisel (1974-1979) & 18 & 8 & 14 & $86 \%$ \\
Figueiredo (1979-1985) & 21 & 4 & 15 & $93 \%$ \\
Sarney (1985-1990) & 22 & 1 & 11 & $91 \%$ \\
Collor (1989-1992) & 20 & 4 & 11 & $82 \%$ \\
Franco (1992-1995) & 13 & 4 & 4 & $75 \%$ \\
Cardoso I (1995-1998) & 19 & 6 & 11 & $64 \%$ \\
Cardoso II (1999-2002) & 21 & 6 & 13 & $85 \%$ \\
Lula I (2003-2006) & 20 & 5 & 12 & $83 \%$ \\
Lula II (2007-2010) & 21 & 4 & 12 & $100 \%$ \\
Rousseff I (2011-2014) & 13 & 0 & 6 & $100 \%$ \\
Rousseff II (2015-) & 13 & 4 & 4 & $100 \%$ \\
\hline
\end{tabular}

Sources: Brazil (n.d.), Anuário do pessoal do Serviço Exterior, 1973-1983; Brazil (n.d.), Relatório anual da Presidência do Senado, 2000-2015; Garcia (2005); CPDOC/FGV Historical Archive (https://cpdoc.fgv.br/acervo/dhbb).

${ }^{a}$ Total number of ambassadors who served in top ten embassies, for each presidential term.

${ }^{\mathrm{b}}$ Number of ambassadors changed in the first year of presidency in top ten embassies.

${ }^{\mathrm{c}}$ Total of ambassadors appointed by a president for these embassies, in each presidential term.

d Percentage of career diplomats appointed over the total of "ambassadors designated $(n)$ " in top ten embassies.

for 1985-2015. Since the second Lula administration, all Brazilian top-ten ambassadors have been career diplomats. Although the stability of the ambassadorial elite decreased since the mid-1990s, its structure as a professional body has strengthened. In fact, professionalism of the ambassadorial elite is the area in which presidential delegation to the foreign ministry has reached its peak.

\section{Foreign Ministers}

Table 4 shows two attributes of Brazilian foreign ministers since 1946: the high frequency of experts and the relatively low frequency of seating congresspeople. The interregime variation in the frequency of career diplomats heading the foreign ministry is considerable: 6 percent in 1946-1964, 80 percent in 1964-1985, and 57 percent in 1985-2015. However, if we consider only the 1995-2015 period, no less than 87 percent of the foreign ministers have been career diplomats. So the past twenty years have seen the largest share of diplomats heading the foreign ministry since 1946. Paradoxical though it may sound, this is evidence that presidents have been delegating less foreign policy authority to the foreign ministry. Such evidence is consistent with our data on presidential activism as measured by the frequency of state visits.

Since 1946 Brazil has been increasingly satisfying the necessary condition for a strong foreign ministry: the professionalization of the diplomatic corps (Belém Lopes 2013). As for the substitutable conditions 
Table 4: Criteria for the selection of Brazilian foreign ministers by regime, 1946-2015.

\begin{tabular}{lrrrrrr} 
& \multicolumn{1}{c}{$\mathbf{1 9 4 6}-\mathbf{1 9 6 4}$} & $\mathbf{1 9 6 4 - 1 9 8 5}$ & \multicolumn{1}{c}{$\mathbf{1 9 8 5}-\mathbf{2 0 1 5}$} \\
\cline { 2 - 7 } & \multicolumn{1}{c}{$\boldsymbol{N}$} & \multicolumn{1}{c}{$\%$} & $\boldsymbol{N}$ & $\mathbf{9}$ & $\boldsymbol{N}$ & $\mathbf{\%}$ \\
\hline Party members & 15 & $94 \%$ & 1 & $20 \%$ & 5 & $33 \%$ \\
Career diplomats & 1 & $6 \%$ & 4 & $80 \%$ & 8 & $53 \%$ \\
Experts & 15 & $94 \%$ & 4 & $80 \%$ & 12 & $80 \%$ \\
Legislators & 3 & $19 \%$ & 1 & $20 \%$ & 1 & $7 \%$ \\
Total $N$ of ministers & 16 & & 5 & & 15 & \\
\hline
\end{tabular}

Sources: Brazil, Ministério das Relações Exteriores, http://www.itamaraty.gov.br; Amorim Neto (2011).

(institutional attributions and presidential delegation), there has been considerable variation. Since the mid1990s, Itamaraty has been losing attributions in the form of competition from other state bureaucracies and presidential advisers. The foreign ministry has also been delegated less authority by presidents, owing to their growing activism and their unwillingness to appoint politically strong foreign ministers. Ironically, it was at the peak of Brazil's international prestige-under Cardoso and Lula-that the country's foreign ministry lost a great deal of its influence. Despite this downfall, Itamaraty retains a relatively high policymaking capacity, especially because presidents keep appointing career diplomats to head the country's top embassies and because of diplomats' hold over key offices within the ministry.

That said, according to our concept and measures, the golden age of Itamaraty has passed. This age went from the 1940s to the 1980s, when the professionalization of the diplomatic corps was growing apace, presidents were generally not active in foreign policy, the ambassadorial elite was moderately stable and composed mostly of career people, foreign ministers were relatively powerful politicians, and peer competition from other state agencies was mild, except for the armed forces.

\title{
Mexico: A Permanently Marginal Foreign Ministry
}

The Secretariat of Foreign Affairs (SRE, by its Spanish acronym) deals with Mexico's international relations including tourism and, only formally, trade. With the few mentioned exceptions, Mexico's foreign secretaries have been relatively low-profile politicians, particularly after 1994 (see Table 6).

Career diplomats began to be recruited through public examinations in 1967, when training and education became an important part of career development. This "is now based on both time served and merit. Promotions are obtained through competitive examinations" (Rozental 1999, 147). Mexico's diplomatic school, the Instituto Matías Romero, was created in 1974.

What was the SRE like before professionalization? Rozental $(1999,142-143)$ summarizes it as follows:

\begin{abstract}
Directors and Subsecretarios in the SRE were generally much older than their counterparts in other ministries, and consequently more prone to caution and tradition. If to this inherent imbalance one adds the fact that most career diplomats up until 1970 were lawyers trained in the minutiae of their profession, it is easy to understand the clash that arose between them and their colleagues. Popular imagery had diplomats standing around at cocktail parties, drinking champagne and dancing in their tuxedoes in faraway foreign capitals. No one thought diplomats good for much else than reporting home on gossip gleaned in spy-like encounters, or helping obtain hard-to-get tickets for the theatre. So it became imperative for the diplomatic service to change its image.
\end{abstract}

As for competition with defense-related agencies, Mexico's cabinet includes a secretary of defense, in charge of the army and air force. The navy enjoys a separate secretary. Both secretaries have the same rank and report to the president, who is the head of all armed forces. The Mexican military, unlike their Argentine and Brazilian counterparts, has not played any major political role during the period under study and, therefore, has not had disputes over competences with the foreign secretary. Moreover, article 76 of the Mexican Constitution and the statutory laws of the army and the navy do not allow them to operate abroad on unilateral orders of the two defense-related secretariats.

The existence of a national security council is a fuzzy issue, as there is a security cabinet coordinated by the presidential office with representatives of other agencies, such as the attorney general and the intelligence 
services. Yet that cabinet does not enjoy policy autonomy. Neither does the post of foreign affairs adviser, which existed under the tenure of Calderón (2006-2012) but not Peña Nieto (2012-2018).

Mexico's foreign secretary has a secondary role regarding trade policy (Figueroa and Schiavon 2014, 15; Rozental 1999, 137). Since 1946, this policy has been conducted by the economy secretary. The negotiation of the North American Free Trade Agreement (NAFTA), arguably the paramount decision in Mexican foreign policy and a historical about-face, was carried out by a team that did not include a single member from SRE and was led by the Secretariat of Trade and Industrial Development, as the Secretariat of Economy was called until 2000 (Coelho 2014).

Although we have found evidence that deputy chiefs of embassies are a preserve of career diplomats, these are not top offices. In addition, deputy foreign ministers are frequently career diplomats, but this is not mandated by law.

In sum, while SRE has faced very mild competition from defense-related agencies, the country's economic bureaucracy is a formidable competitor of the foreign ministry, which has not even had a strong hold over key diplomatic offices. We conclude that SRE's policy-making capacity has never been backed by strong institutional attributions.

\section{The International Travels of the President}

Mexican presidents take office in December of the election year, but most travels start only after January of the following year. Only Ernesto Zedillo (1994-2000) traveled shortly after taking office: he spent four days in the United States in December 1994. This is probably the best indicator of the reasons the frequency of presidential travels increased during the two decades that followed 1991: the signing of NAFTA, a freetrade agreement with the United States and Canada to regulate the high levels of interdependence among these countries (Figure 4). Even so, only in 2001 did presidential time spent abroad overcome the 1974 peak, when Luis Echeverría (1970-1976) took advantage of the oil crisis to project Mexico's image abroad.

A complementary explanation for the increase of international traveling during the 1990s is the need to balance the Mexican dependence on the United States. Presidents diversified their destinations, especially to Latin America, to signal that the establishment of NAFTA did not mean that Mexico conferred political or economic exclusivity to its northern neighbor. After the tenures of Zedillo and Fox, the intensity of international travels fell to its previous average.

\section{The Ambassadorial Elite}

Based on political or commercial salience over all or a significant part of the period, we identified ten embassies as top Mexican destinations: Canada, Cuba, France, Italy, Japan, Russia, Spain, United Kingdom, United States, and the permanent UN mission. Regime change is not the main predictor of the ambassadors'

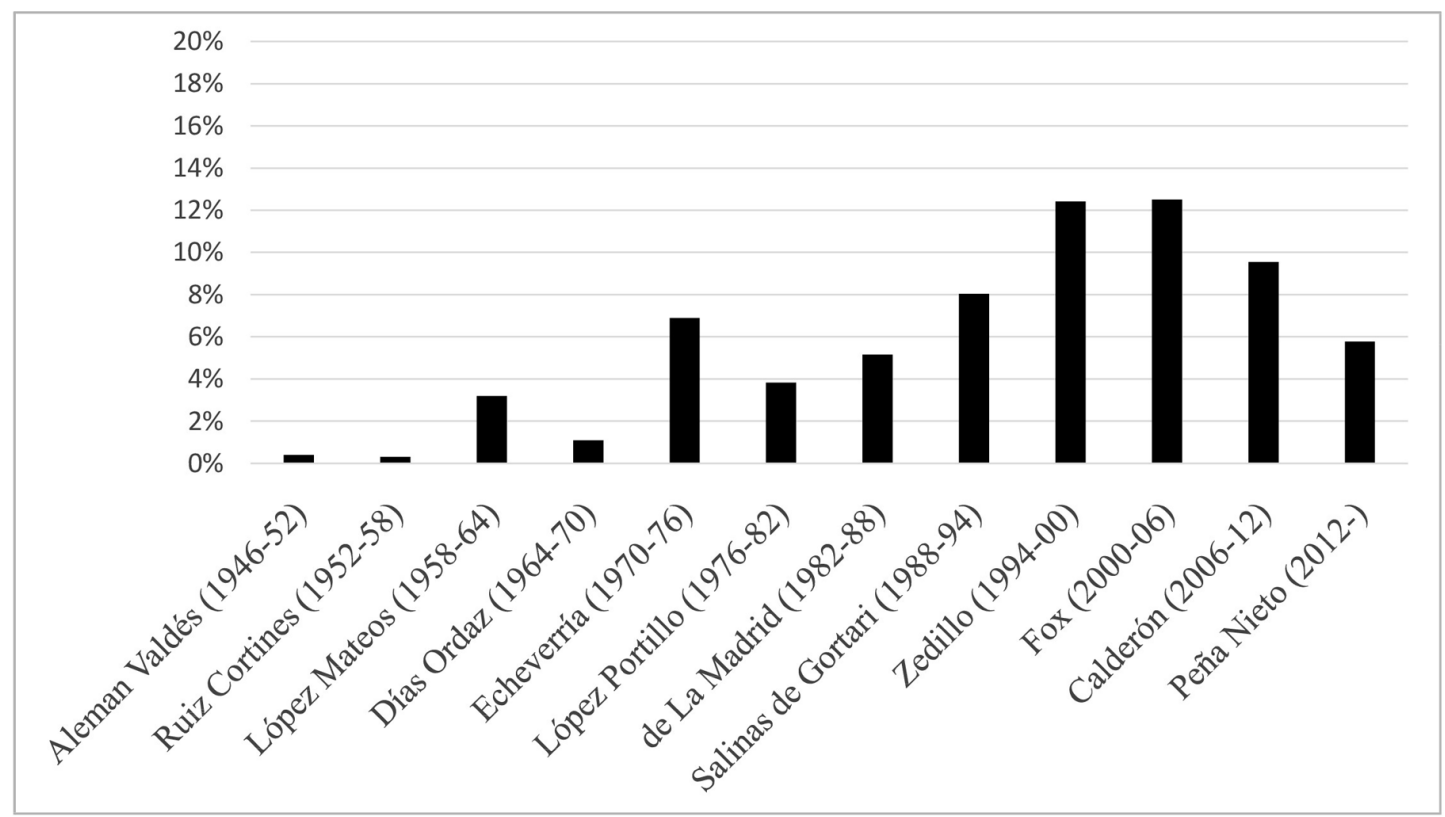

Figure 4: Percentage of term spent abroad by Mexican presidents, 1946-2015 (Archive of Mexico's Secretaría de Relaciones Exteriores). 
profile. There was a majority of professional diplomats in charge until 1964, and then again from 1994. Considering that the administration inaugurated in 1994 was led by the Institutional Revolutionary Party (Partido Revolucionario Institucional), just as it had been since the 1930s, party alignment does not explain variation either. In the middle period, without undergoing party or regime change, the percentage of diplomats in top embassies fell to well below 50 percent (to an average of just above 30 percent). In contrast, both before 1964 and after 1994 the percentage of professional diplomats was always above 50 percent and averaging 60 percent (Table 5).

\section{Foreign Ministers}

As a result of regime change, we divided the 1946-2015 period in two: 1946-1994 and 1994-2015. Following Camp (2011), we selected this cutoff because the choice of Ernesto Zedillo as the PRI's presidential candidate was key to consolidating the country's transition to democracy. Table 6 indicates that the combination of lasting foreign policy concerns and high domestic stability led to a low rotation of foreign ministers. Indeed, almost half took power and left it at the same time as the president who appointed them. However, in the past two decades there has been an impressive decline in the percentage

Table 5: Changes promoted by Mexican presidents in top ten embassies, 1946-2015.

\begin{tabular}{lrrrr} 
President & $\begin{array}{c}\text { Ambassadors } \\
(\boldsymbol{n})^{\mathbf{a}}\end{array}$ & $\begin{array}{c}\text { Changes } \\
\text { made in } \\
\text { first year }^{\mathbf{b}}\end{array}$ & $\begin{array}{c}\text { Ambassadors } \\
\text { designated } \\
(\boldsymbol{n})^{\mathbf{c}}\end{array}$ & $\begin{array}{c}\text { Career } \\
\text { diplomats }^{\text {appointed }}\end{array}$ \\
\hline Alemán Valdés (1946-1952) & 24 & 4 & 16 & $63 \%$ \\
Ruiz Cortines (1952-1958) & 26 & 6 & 17 & $53 \%$ \\
López Mateos (1958-1964) & 25 & 4 & 16 & $63 \%$ \\
Díaz Ordaz (1964-1970) & 26 & 7 & 17 & $29 \%$ \\
Echeverría (1970-1976) & 23 & 5 & 14 & $29 \%$ \\
López Portillo (1976-1982) & 37 & 11 & 28 & $32 \%$ \\
de la Madrid (1982-1988) & 29 & 8 & 19 & $42 \%$ \\
Salinas de Gortari (1988-1994) & 42 & 8 & 32 & $28 \%$ \\
Zedillo (1994-2000) & 28 & 10 & 18 & $50 \%$ \\
Fox (2000-2006) & 32 & 9 & 22 & $73 \%$ \\
Calderón (2006-2012) & 23 & 6 & 13 & $62 \%$ \\
Peña Nieto (2012-2015) & 21 & 7 & 12 & $58 \%$ \\
\hline
\end{tabular}

Source: Mexico's ambassadors and embassies, http://acervo.sre.gob.mx/index.php?option=com_content\&view=article \&id=225\&Itemid=346.

${ }^{a}$ Total number of ambassadors who served in top ten embassies, for each presidential term.

${ }^{\mathrm{b}}$ Number of ambassadors changed in the first year of presidency in top ten embassies.

${ }^{\mathrm{c}}$ Total of ambassadors appointed by a president for these embassies in each presidential term.

${ }^{\mathrm{d}}$ Percentage of career diplomats appointed over the total of "ambassadors designated $(n)$ " in top ten embassies.

Table 6: Criteria for the selection of Mexican foreign ministers by regime, 1946-2015.

\begin{tabular}{lcccc} 
& \multicolumn{2}{c}{$\mathbf{1 9 4 6}-\mathbf{1 9 9 4}$} & \multicolumn{2}{c}{$\mathbf{1 9 9 4}-\mathbf{2 0 1 5}$} \\
\cline { 2 - 5 } & $\boldsymbol{N}$ & $\mathbf{\%}$ & $\boldsymbol{N}$ & $\mathbf{\%}$ \\
\hline Party members & 9 & $64 \%$ & 6 & $86 \%$ \\
Career diplomats & 7 & $50 \%$ & 2 & $29 \%$ \\
Experts & 9 & $64 \%$ & 3 & $43 \%$ \\
Legislators & 9 & $64 \%$ & 1 & $14 \%$ \\
Total $N$ of ministers & 14 & & 7 & \\
\hline
\end{tabular}

Sources: Mexico's foreign secretaries' biographies by the Secretariat of Foreign Affairs, http://sre.gob.mx/siglo-xx; Camp (2011). 
of foreign ministers who held legislative office: from 64 percent in 1946-1994 to 14 percent in 19942015. This means a reduction in the political autonomy of such ministers, which translates into lower foreign ministry policy-making capacity.

According to Quijano Torres (2012), Mexican foreign ministers were appointed for six reasons: political expediency, professional merits, membership in the elite, friendship, ideology, and imposition by de facto powers. Differences in the pattern of recruitment between old and new regimes are not great. The most visible alteration is a slight increase of experts to the detriment of party politicians after 1994. This should not come as a surprise, as National Action Party (Partido Acción Nacional, PAN), the party that governed Mexico in 2000-2012, is more technocratic than the PRI-the party that governed the country in 19462000 and again since 2012-and has a smaller apparatus to maintain.

The PRI comeback of 2012 did not mean an increase in the power of the foreign secretary. Indeed, the president changed his secretary by midterm and appointed one who had been, until then, secretary of tourism. This suggests that foreign affairs continue to be located in the realm of low politics.

All told, since the late 1960s Mexico has been increasingly satisfying our necessary condition for a strong foreign ministry: the professionalization of its diplomatic corps. As regards the substitutable conditions, though, there has not been much variation in institutional attributions since 1946. In addition, like its Argentine counterparts, from the late 1980s to the late 2000s, Mexico's foreign ministry was delegated less authority by presidents, who displayed growing activism through international travels. Finally, since democratization and turnover in 2000, the appointment of heavyweight politicians has not heightened the policy-making capacity of Mexico's foreign ministry. SRE remains a not-so-weak foreign ministry only because presidents keep appointing a majority of career diplomats to head the country's top embassies.

\section{Conclusions}

Figure 5 summarizes our findings. Given that our concept of policy-making capacity has three constitutive elements, we need three-dimension graphs to represent it. Such graphs are usually difficult to visualize and interpret. However, by using a shaded area to characterize professionalization (or the $z$ axis), the resulting figures are a "user-friendly" manner to elaborate three-dimensional graphs.

Argentina, Brazil, and Mexico enjoy a high level of professionalization of their diplomatic corps. This means that the necessary condition for a foreign ministry to display high policy-making capacity is met in all three countries. Differences remain as regards the two substitutable dimensions: institutional attributions and presidential delegation. The former has been traditionally minimal in Argentina and Mexico and is declining in Brazil, whereas the latter has been highly irregular in Argentina, sporadic in Mexico and, again, declining in Brazil. Institutional attributions have suffered a rollback given the growing intervention-and professionalization-of other state agencies, mainly defense or economy ministries (depending on the country). This is not an uncommon pattern: decades ago, Rubin (1985) documented the relative decline of the State Department vis-à-vis the National Security Council staff and White House advisers. More recently, Wrage (2008) evaluated the changing balance of influence over foreign policy between the US Department of State and the Pentagon since the 1940s, showing the impressive decline of the former under President George W. Bush. Our article is the first attempt to identify, measure, and compare similar processes in Latin America.

In turn, presidential delegation has receded as stronger presidents, whether their strength derived from regime change, ideological turns or personal character, withdrew competencies their predecessors had handed over to foreign ministers or professional diplomats. The blossoming of presidential diplomacy over the past three decades has taken its toll on professional diplomacy and its bedrock, the foreign ministry.

The link between democratization and the weakening of foreign ministries is not straightforward. Brazil strengthened its professional diplomacy in the 1946-1964 democratic period, whereas Argentina created its diplomatic institute under a provisional government that ensued from a coup and Mexico did alike under a nondemocratic regime.

As concerns institutional attributions, the Brazilian foreign ministry has always been stronger than its counterparts, mostly regarding trade policy. Yet since the 1990s, growing policy competition and presidential diplomacy have reduced Itamaraty's policy-making capacity.

All three foreign ministries saw their policy-making capacity lowered during the twenty-first century, which should be credited to increasing presidential activism irrespective of ideological leaning. However, Brazil's and Mexico's foreign ministries were able to stabilize the losses through professional diplomats' heading of the majority of the countries' top embassies. The appointment of politicians who enjoyed both civil society consideration and presidential confidence to head the foreign ministry was another opportunity, albeit fleeting, for the diplomatic service to see its policy-making capacity enhanced. 


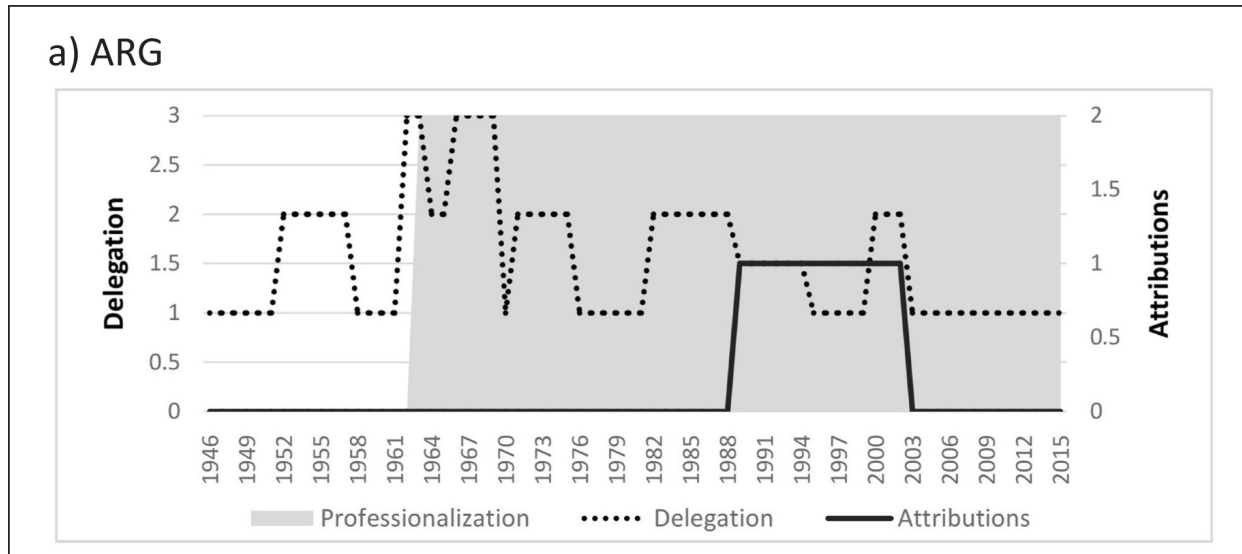

b) BRA

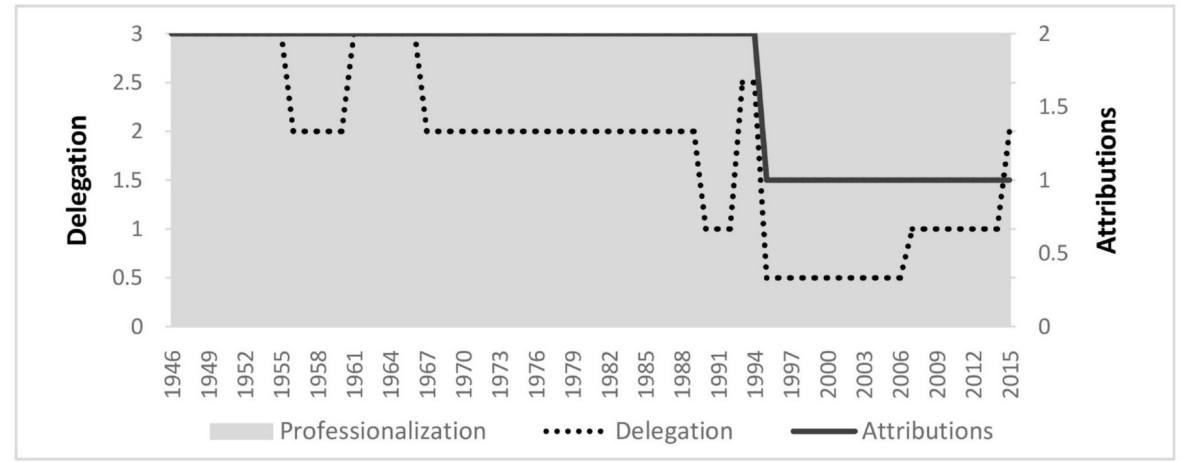

c) MEX

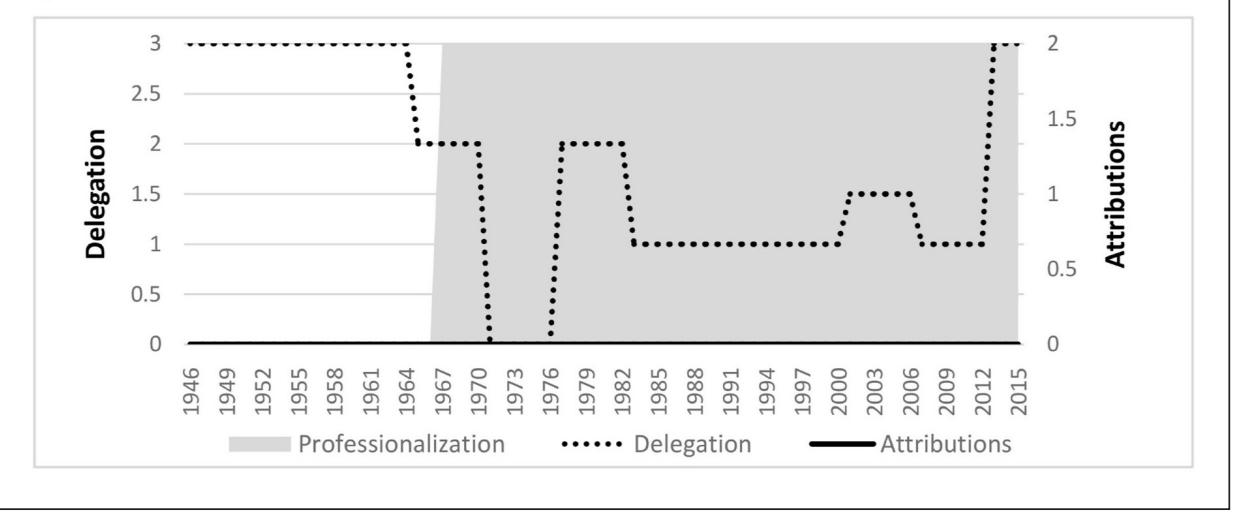

Figure 5a-c: Foreign ministry policy-making capacity, 1946-2015, in Argentina, Brazil, and Mexico. Notes: "Professionalization" is coded 3 when a country has a professionalized foreign ministry in a given year, otherwise 0 (left axis): this is represented by the shaded area. "Attributions" is composed of two indicators and "Delegation" of three, as explained in the text. Their scores are coded 1 when a country meets a given condition in a given year, 0.5 when a country meets that condition partially, and 0 otherwise. Thus, the score range for "Attributions" varies from 0 to 2 (right axis), whereas "Delegation" varies from 0 to 3 (left axis). The raw values are shown in the appendixes.

We have shown how the policy-making capacity of Latin American foreign ministries varied over the years: Argentina's pattern is volatile, Brazil's starts at a high position and declines gradually, and Mexico's stays relatively stable at an intermediate level. If anything, this is a confirmation of Hocking's (1999b, 14) claim that "generalizations about foreign ministries, their role and significance are fraught with danger." The empirical contribution of this article means that we no longer need to generalize: we now know how much policy-making capacity the top Latin American foreign ministries hold and how it has evolved over time.

Our theoretical contribution is no less ambitious, as our conceptualization was designed to travel beyond Latin America and can be applied to measure the policy-making capacity of foreign ministries in any presidential or semipresidential regime. A broad research agenda unwraps before us. 


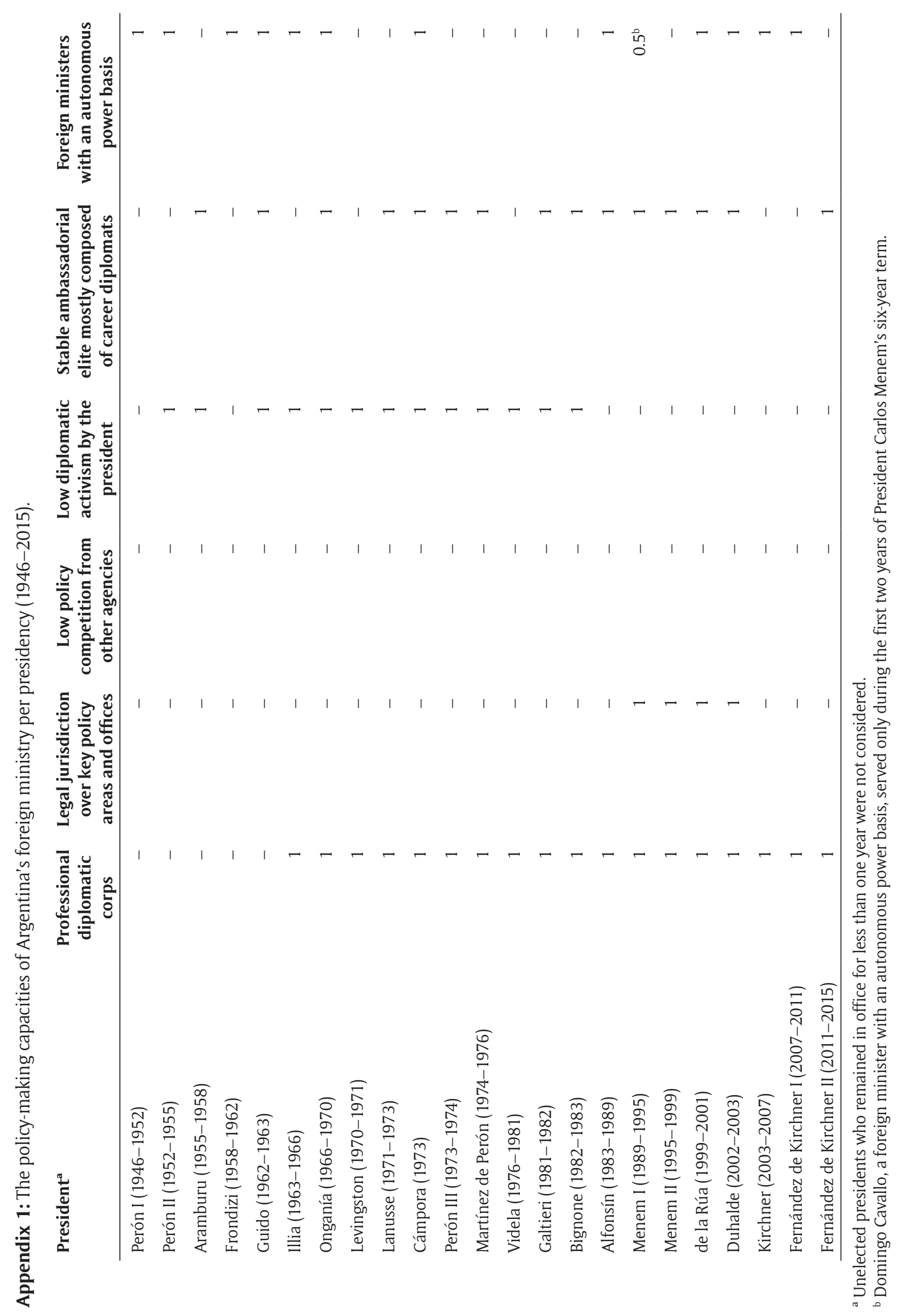




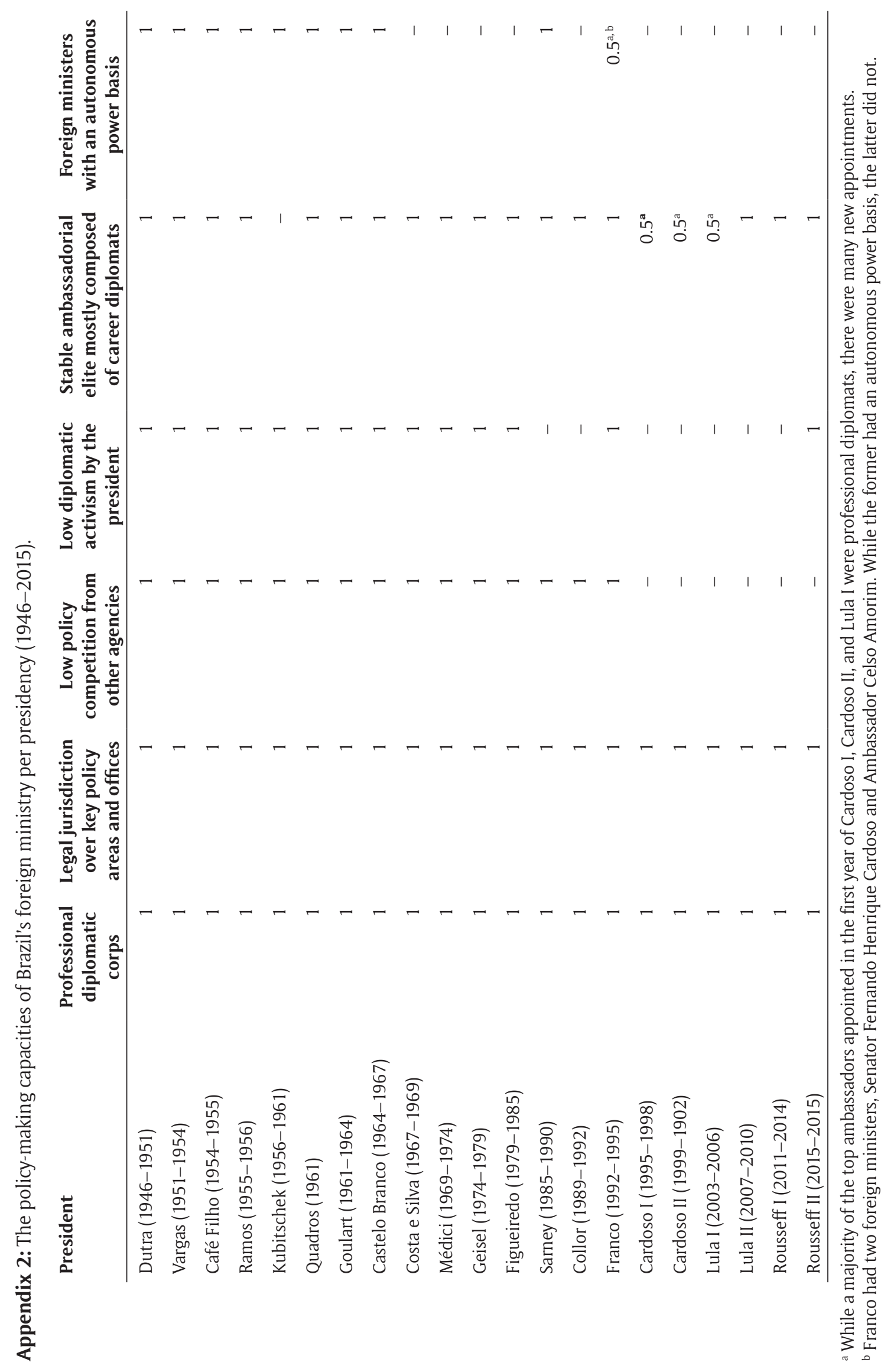




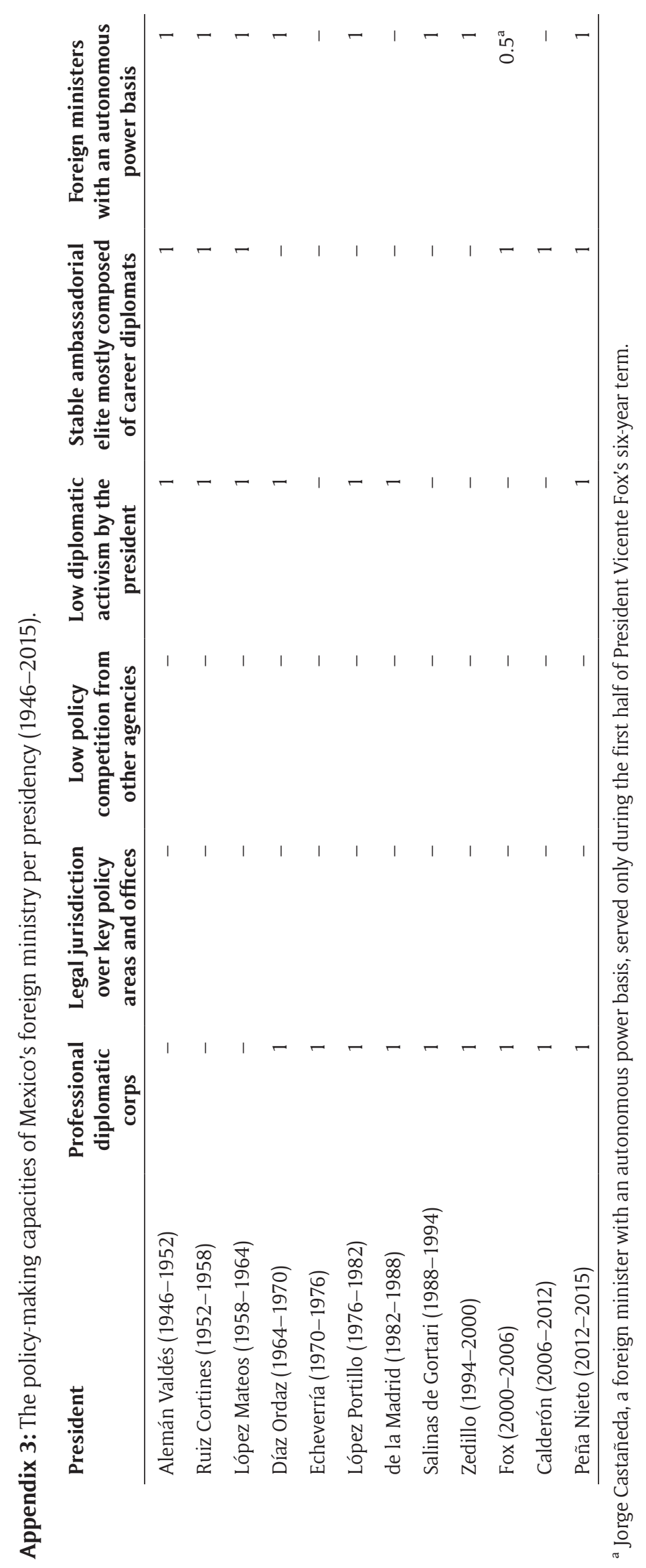




\section{Acknowledgements}

A previous version of this article was presented at the 57th International Studies Association Annual Convention (ISA), March 16-19, 2016, in Atlanta. Igor Acácio, Pedro Accorsi, André Anselmo, Bruna Cavalcanti, Camila Farias, and Gino Pauselli provided superb research assistance. We thank João Paulo Alsina Jr., Dawisson Belém Lopes, Carlos Closa, Carlos Coelho, Martín Costanzo, Miguel De Luca, Carlos Pimenta de Faria, Gelson Fonseca, Gregory Michener, Antonio Ortiz-Mena, Andrés Rojas, Jorge Schiavon, Arturo Sotomayor, Cameron Thies, and three anonymous LARR reviewers for generous comments or advice.

\section{Author Information}

Octavio Amorim Neto received his PhD in political science from the University of California at San Diego (1998). He is currently full professor at the Brazilian School of Public and Business Administration at the Getulio Vargas Foundation, Rio de Janeiro. His research interests are comparative political institutions, Brazil, Latin America, Portugal, foreign policy-making, and civil-military relations and defense policy.

Andrés Malamud is a senior research fellow at the Institute of Social Sciences of the University of Lisbon. He earned his doctorate in 2003 from the European University Institute in Florence. A comparativist by training, his research interests focus on regional integration, foreign policy, political institutions, Latin American politics, and EU studies.

\section{References}

Allison, Graham T., and Philip Zelikow. 1999. Essence of Decision. New York, NY: Longman.

Amorim Neto, Octavio. 2011. De Dutra a Lula: A condução e os determinantes da política externa brasileira. Rio de Janeiro: Campus.

Arias, Eric, and Alastair Smith. 2018. "Tenure, Promotion and Performance: The Career Path of U.S. Ambassadors." Review of International Organizations 13 (1): 77-103. DOI: https://doi.org/10.1007/ s11558-017-9277-0

Belém Lopes, Dawisson. 2013. Política externa e democracia no Brasil. São Paulo: Editora UNESP.

Bosoer, Fabián. 2005. Generales y embajadores. Buenos Aires: Editorial Vergara.

Brazil. n.d. Anuário do pessoal do Serviço Exterior, 1973-1983. http://www.funag.gov.br/chdd/index.php/ anuario-de-funcionarios-do-mre.

Brazil. n.d. Relatório anual da Presidência do Senado, 2000-2015. Brasília: Senado. https://www25.senado .leg.br/web/atividade/relatorio-da-presidencia/1999-em-diante.

Camp, Roderic A. 2011. Mexican Political Biographies, 1935-2009. Austin: University of Texas Press.

Cason, Jeffrey W., and Timothy J. Power. 2009. "Presidentialization, Pluralization, and the Rollback of Itamaraty: Explaining Change in Brazilian Foreign Policy Making in the Cardoso-Lula Era." International Political Science Review 30 (2): 117-140. DOI: https://doi.org/10.1177/0192512109102432

Castro, Flavio M. O., and Francisco M. O. Castro. 2009. Dois séculos de história da organização do Itamaraty (1808-2008). 2 vols. Brasília: Fundação Alexandre Gusmão.

Cheibub, Zairo B. 1985. "Diplomacia e construção institucional: O Itamaraty em uma perspectiva histórica." Dados 28 (1): 13-30.

Cisneros, Andrés, and Carlos Escudé, eds. 2000. Historia general de las relaciones exteriores de la República Argentina: Las relaciones exteriores de la Argentina embrionaria. Vol. 14. Buenos Aires: Centro de Estudios de Política Exterior. http://www.argentina-rree.com/historia_indice00.htm.

Coelho, Carlos F. 2014. "O Brasil, o México e a proliferação de acordos comerciais regionais (1989-2012)." PhD diss., Rio de Janeiro State University.

Conselho de Segurança Nacional (Brazil). 1969. Decreto-Lei nº 900, September 29, 1969. http://www .planalto.gov.br/ccivil_03/Decreto-Lei/Del0900.htm.

Danese, Sérgio F. 1999. Diplomacia presidencial. Rio de Janeiro: Topbooks.

East, Maurice A., and C. Edward Dillery. 1999. "The United States: The State Department's Post-Cold War Status." In Foreign Ministries: Change and Adaptation, edited by Brian Hocking, 226-246. New York: Macmillan. DOI: https://doi.org/10.1007/978-1-349-27317-1_14

Figueroa, Bruno, and Jorge Schiavon. 2014. "Brasil y México: Inversión y capacidades en política exterior." Foreign Policy Edición Mexicana 3 (16): 12-15.

Garcia, Eugenio V. 2005. Cronologia das relações internacionais do Brasil. Rio de Janeiro: Contraponto.

Goertz, Gary. 2006. Social Science Concepts: A User's Guide. Princeton, NJ: Princeton University Press. DOI: https://doi.org/10.1515/9781400842995 
Hocking, Brian, ed. 1999a. Foreign Ministries: Change and Adaptation. New York: Macmillan. DOI: https:// doi.org/10.1007/978-1-349-27317-1

Hocking, Brian. 1999b. "Foreign Ministries: Redefining the Gatekeeper Role." In Foreign Ministries: Change and Adaptation, edited by Brian Hocking, 1-15. New York: Macmillan. DOI: https://doi.org/10.1007/9781-349-27317-1_1

Hocking, Brian, and David Spence, ed. 2003. Foreign Ministries in the European Union: Integrating Diplomats. New York: Palgrave. DOI: https://doi.org/10.1057/9780230502970

Huntington, Samuel P. 1968. Political Order in Changing Societies. New Haven, CT: Yale University Press.

Mahoney, James, Erin Kimball, and Kendra L. Koivu. 2009. "The Logic of Historical Explanation in the Social Sciences." Comparative Political Studies 42 (1): 114-146. DOI: https://doi.org/10.1177/0010414008325433

Malamud, Andres. 2005. "Presidential Diplomacy and the Institutional Underpinnings of MERCOSUR: An Empirical Examination." Latin American Research Review 40 (1): 138-164. DOI: https://doi.org/10.1353/ lar.2005.0004

Malamud, Andres. 2017. "Foreign Policy Retreat: Domestic and Systemic Causes of Brazil's International Rollback." Rising Powers Quarterly 2 (2): 149-168.

Mallea, Rodrigo, Matias Spektor, and Nicholas J. Wheeler, eds. 2015. Los orígenes de la cooperación nuclear: Una historia oral crítica entre Argentina y Brasil. Rio de Janeiro: Fundação Getúlio Vargas and Woodrow Wilson Center for Scholars.

Miyamoto, Shiguenoli, and Williams S. Gonçalves. 1993. "Os militares e a política externa brasileira: 19641984." Estudos Históricos 6 (12): 211-246.

Pinheiro, Leticia, and Carlos R. S. Milani, eds. 2012. Política externa brasileira: As práticas da política e a política das práticas. Rio de Janeiro: FGV.

Quijano Torres, Manuel. 2012. Los gabinetes en México: 1821-2012. Vol. 3. Mexico City: Instituto de Administración Pública.

Roblas, Constantino. 2011. "El servicio exterior de la nación en el siglo XXI ¿Avances o retrocesos?" Escenarios Alternativos, February 12. http://www.escenariosalternativos.org/default.asp?nota=3924.

Rockman, Bert. 1997. "The Performance of Presidents and Prime Ministers and of Presidential and Parliamentary Systems." In Presidential Institutions and Democratic Politics, edited by Kurt von Mettenheim, 45-64. Baltimore: Johns Hopkins University Press.

Rodman, Peter W. 2010. Presidential Command: Power, Leadership, and the Making of Foreign Policy from Richard Nixon to George W. Bush. New York: Vintage Books.

Rozental, Andrés. 1999. "Mexico: Change and Adaptation in the Ministry of Foreign Affairs." In Foreign Ministries: Change and Adaptation, edited by Brian Hocking, 133-151. New York: Macmillan. DOI: https://doi.org/10.1007/978-1-349-27317-1_9

Rubin, Barry. 1985. Secrets of State: The State Department and the Struggle over U.S. Foreign Policy. New York: Cambridge University Press.

Samuels, David J., and Matthew S. Shugart. 2010. Presidents, Parties, and Prime Ministers: How the Separation of Powers Affects Party Organization and Behavior. New York: Cambridge University Press. DOI: https:// doi.org/10.1017/CBO9780511780882

Steiner, Zara S., ed. 1982. The Times Survey of Foreign Ministries of the World. London: Times Books. DOI: https://doi.org/10.2307/40202061

Stepan, Alfred C. 1988. Rethinking Military Politics: Brazil and the Southern Cone. Princeton, NJ: Princeton University Press.

Weaver, R. Kent, and Bert Rockman. 1993. "When and How Do Institutions Matter?" In Do Institutions Matter? Government Capabilities in the U.S. and Abroad, edited by R. Kent Weaver and Bert Rockman, 445-461. Washington, DC: Brookings Institution Press.

Wrage, Stephen D. 2008. "The Department of Defense and the Department of State: Out of Balance and into Trouble." In Inside Defense: Understanding the U.S. Military in the 21st Century, edited by Derek S. Reveron and Judith Hicks Stiehm, 15-29. New York: Palgrave Macmillan. DOI: https:// doi.org/10.1057/9780230613782_2 
How to cite this article: Amorim Neto, Octavio, and Andrés Malamud. 2019. The Policy-Making Capacity of Foreign Ministries in Presidential Regimes: A Study of Argentina, Brazil, and Mexico, 1946-2015. Latin American Research Review 54(4), pp. 812-834. DOI: https://doi.org/10.25222/larr.273

Submitted: 28 August 2017

Accepted: 05 March 2018

Published: 11 December 2019

Copyright: (c) 2019 The Author(s). This is an open-access article distributed under the terms of the Creative Commons Attribution 4.0 International License (CC-BY 4.0), which permits unrestricted use, distribution, and reproduction in any medium, provided the original author and source are credited. See http://creativecommons.org/ licenses/by/4.0/. 